\title{
LA MIRADA MIOPE DE ROBERTO BOLAÑO: ESCRITURA DE LO IN/VISIBLE Y LO IN/SIGNIFICANTE*
}

\author{
THE MYOPIC ROBERTO BOLAÑO: WRITING \\ OF THE IN/VISIBLE AND IN/SIGNIFICANT
}

Claudia Tapia

Universidad Católica de la Santísima Concepción. Concepción, Chile ctapia@ucsc.cl

\begin{abstract}
Resumen: Las dioptrías de la enfermedad del ojo de Roberto Bolaño le obligaron a una mirada informe y borrosa de la realidad. Su manera de ver se trasladó a una literatura que en un juego de alejamientos y aproximaciones con el objeto de observación, deforma, oculta y exagera. El resultado es una ficción visualmente denigrada que dista en extremo de la perspectiva regular que propone un régimen epistemológico que ha confiado en el "más noble" de los sentidos. Tras las historias visibles de Los detectives salvajes, Nocturno de Chile, Estrella distante y 2666 se oculta una trama secreta que nunca será develada, paradojal manera de visibilizar la imposibilidad del sentido de la experiencia.
\end{abstract}

Palabras clave: Literatura, visualismo, estética de la desaparición, Roberto Bolaño.

\begin{abstract}
Roberto Bolaño's diopter correction forced him to develop an informative and blurred perspective of reality. This view has been translated to literature where the object of observation becomes deformed, hidden, or exaggerated as a result a closer or more distant look to the observed subject or object. The result is a visually denigrated fiction, far from the regular epistemological perspective proposed by the "most noble" of the senses. After visible stories such as The Savage Detectives, By Night in Chile, Distant Star and 2666 a secret and never unveiled plot is hiding - a paradoxical way to visualize the impossibility of the sense of experience.
\end{abstract}

Keywords: Literature, visualism, the aesthetics of disappearance, Roberto Bolaño.

Recibido: 22.09.2014. Aceptado: 26.03.2015.

* Este artículo es resultado de la investigación doctoral "El punto caecum de la crítica literaria: La enfermedad del ojo en los detectives de Roberto Bolaño y Ricardo Piglia”, realizada por la autora en el Programa de Doctorado en Literatura Latinoamericana de la Facultad de Humanidades y Arte de la Universidad de Concepción (Concepción, Chile). Profesor guía: Mario Rodríguez Fernández. 
$\mathrm{H}^{2}$ AY UN VínCULO entre arte y miopía que no deja de ser sugerente, enigmático y perturbador. Muchos pintores sufrieron esa ametropía. Monet, Renoir, Cézanne, Degas, Matisse, Pizarro, Lautrec, Rodin... veían mal. Esa característica fue compartida también por compositores como Beethoven, Schubert, Wagner, Bach, Bizet, Mahler, Schostakovitsch y Stravinski. En literatura, la enfermedad del ojo fue condición de la obra de Francisco de Quevedo, Jorge Luis Borges, Gustave Flaubert, Mircea Eliade, James Joyce, Giovanni Papini. También la de Roberto Bolaño. Todos ellos integrarían una de las dos cofradías literarias que existen, según Du Camp en Souvenirs littéraires:

(...) toda la literatura puede dividirse en dos escuelas diferentes, la de los miopes y la de los présbites. Los miopes ven por los bordes, le dan importancia a cada cosa porque cada cosa se les aparece aisladamente (...) se diría que tienen un microscopio en el ojo que todo lo aumenta, lo deforma (...) Los présbites, al contrario, ven el conjunto, en el cual los detalles desaparecen para formar una suerte de armonía general (citado por Tabarovsky, 2011: 88).

Este defecto del ojo se manifiesta porque los rayos de luz paralelos procedentes del infinito sufren una refracción excesiva, formando la imagen en un punto focal situado delante de la retina, y no sobre ella, como sería lo normal. En la práctica provoca dificultades para enfocar bien los objetos lejanos, generando un déficit de agudeza visual. Se ven figuras borrosas, sin contornos definidos, que no se reconocen con certeza ${ }^{1}$. Esta deficiencia se intenta superar con una mirada que focaliza en segmentos particulares de los cuerpos que se observan, con una extrema aproximación (Borges intentando descifrar las palabras del libro que tiene pegado a la cara).

La miopía representa una de las maneras en que el arte se relaciona con el mundo: el artista ve siempre mal, desajustado respecto de la armonía y nitidez que el poder se empeña en instaurar. Literariamente se traduce en una escritura desmesurada: "Flaubert escribe con una lupa, el espectador mira y cree ver monstruos allí donde no había más que criaturas humanas semejantes a él" (Tabarovsky, 2011: 88).

\footnotetext{
${ }^{1}$ Cézanne confesó: Veo que los planos se sobreponen unos a otros y a veces me parece que las líneas rectas se caen.
} 
Las ficciones de Roberto Bolaño manifiestan su trastorno óptico en historias y discursos que tienden a la invisibilización o a la deformación por acercamiento y distancia. El escritor chileno ensalza la impotencia del ojo en su afán epistemológico y desestabiliza el modelo que secularmente propone a la visión como el sentido predominante e infalible en el camino de acceso a la verdad. Es lo que se desprende del estudio de Estrella distante (1996), Los detectives salvajes (1998), Nocturno de Chile (2000) y 2666 (2004), novelas que desde sus títulos hacen un guiño a la visualidad menoscabada y que además, por su extensión, permiten el análisis de esta toma de posición no solo en la diégesis sino también en el enunciado.

\section{El poder del ojo}

El régimen cultural que ha prevalecido en nuestra civilización desde su nacimiento puede llamarse, con propiedad, ocularcentrismo. Prácticas políticas, sociales, artísticas, religiosas, filosóficas, científicas y domésticas se han basado en la visión, literal y simbólica, como forma de conocimiento.

El modelo se basa en el atributo sensorial que tiene el ser humano para percibir la luz reflejada por los objetos y, por tanto, de conocer las características materiales del entorno. Pero el paradigma ha derivado hacia la capacidad del hombre de dirigir la mirada hacia su interior y, con los "ojos de la mente", reflexionar, saber, teorizar, entender.

En efecto, Occidente ha ungido a la visión como "el más noble de los sentidos", concepto impulsado por la filosofía platónica y su mito de la caverna, relato que fundó la significativa relación entre "ver" y "ser". La Edad Media hizo lo suyo al legar otra de las premisas del ocularcentrismo: nada puede ser conocido por el intelecto si previamente no ha pasado por los ojos. El Barroco, por su parte, provocó una verdadera revolución de la imagen, una "locura de la visión".

El privilegio de la mirada, en todo caso, se instala y consolida con René Descartes y su propuesta de un conocimiento anclado en una visión monocular, incorpórea, ahistórica y objetiva, la que se consigue con la luz que despliega la razón, única vía de acceso a los bienes superiores. A partir de entonces se configura un orden logocularcéntrico que se radicalizará durante la Ilustración. Michel Foucault, en Las palabras y las cosas (1968), 
propone que la Edad Moderna se entienda como el periodo en que las imágenes se liberan de su función narrativa y el mundo se concibe como un sistema puesto para la observación pero carente de un significado per se.

A partir de la videósfera (Debray, 1994) esta omnipresencia de la imagen se radicaliza hasta convertirse en el sello de nuestra época. La "apoteosis de lo visual" está ahora mediatizada por lo digital y lo virtual, un fenómeno que supera las coordenadas del aquí y ahora. Lo óptico se ha independizado de los ojos anatómicos y ya no remite a algo concreto: la realidad ha dejado de ser un patrón que permita distinguir entre verdad e ilusión. Es la "hiperrealidad" de Jean Baudrillard, el mundo de las simulaciones donde las imágenes preceden a sus referentes y por tanto están ajenas al régimen discursivo de la significación.

Michel Foucault es uno de los más conocidos críticos del peligroso andamiaje de la visibilidad. Basándose en el diagrama arquitectónico de Bentham, el pensador francés concibió la sociedad moderna regida por las premisas del panoptismo, un sistema donde opera una dialéctica visual perversa, no recíproca, sin interacción entre el que mira y el que es mirado:

Esta configuración plantea una brutal disimetría en lo que atañe a la visibilidad. El espacio circundado carece de profundidad; se despliega y se abre hacia un único y solitario ojo central. La luz lo baña por completo. Nada ni nadie puede quedar oculto en su interior, excepto la propia mirada, el invisible omnivoyeur. La vigilancia confisca la mirada en su propio beneficio, se apropia de ella y somete al preso a ella (Miller citado por Jay, 2007: 290).

La propuesta de Foucault (2008) cristaliza en las llamadas sociedades disciplinarias, allí donde los mecanismos de vigilancia, legitimados por el racionalismo, pretenden el control y la dominación de los cuerpos. "Ojo" y "razón" son por tanto los factores de un orden que actuará privilegiando la presencia sobre la ausencia, la luminosidad sobre la oscuridad, la plenitud sobre el vacío, lo concreto sobre lo abstracto, lo racional y lógico frente a lo metafórico. La forma de operar responde a una dinámica simple: el que observa convierte al sujeto de su mirada en un objeto de conocimiento, al que individualiza, identifica y diferencia. Es la simbiosis entre saber y poder.

La novela es uno de los muchos dispositivos de esta normalización. Lo plantea Michel Foucault en Vigilar y castigar (2008) y lo refrenda Mario 
Rodríguez (2004): "El poder funciona en todas partes de la máquina de narrar llamada novela, bien sin parar bien discontinuo. El poder introduce lo real en la ficción, enfoca el ojo del narrador, hace bizquear el del lector, determina el orden del discurso, transparenta el mundo narrado" (12).

Es que el registro ficcional actualiza una de las paradigmáticas operaciones disciplinarias, la singularización, pues mientras más particular y mínimo es el conocimiento pretendido, más efectivo es el control:

Y si desde el fondo de la Edad Media hasta hoy la "aventura" es realmente el relato de la individualidad, el paso de lo épico a lo novelesco, de la hazaña a la secreta singularidad, de los largos exilios a la búsqueda interior de la infancia, de los torneos a los fantasmas se inscribe también en la formación de una sociedad disciplinaria (Foucault, 2008: 224).

La novela se ajusta especialmente a las demandas del registro visual de personajes, objetos, acciones, lugares, incluso estados de conciencia. La observación, que discursivamente se traduce en describir, es un procedimiento que no solo produce un "efecto de realidad", como sostuvo Barthes, sino que permite visibilizar al sujeto o al objeto para su adecuado control (lo invisible o vago rehúye el afán normalizador). Ello se ha traducido en un lenguaje de la pormenorización, en el despliegue extremo de los detalles, de los gestos humildes y cotidianos y que han constituido lo que Foucault llama una microfísica del poder, ese terreno menor, pero efectivo, que a través de técnicas minuciosas e ínfimas logra el encauzamiento de las conductas.

\section{La promesa incumplida}

La literatura de Roberto Bolaño manifiesta una marcada proclividad visual a través de dos mecanismos. El primero es la inserción de imágenes en el discurso literario o su evocación a través de la descripción pormenorizada de fotografías, pinturas, paisajes, cuerpos o escenas de películas. El segundo es una visibilidad que se aleja del referente, literal o sugerido, y transparenta más bien una manera de entender el mundo y la literatura. En esta dimensión lo visual se comporta como un revelador poético y axiológico: la mirada es la poética del autor. 
La mayoría de los estudios sobre el visualismo del escritor chileno se centran en la primera dimensión. Valeria de los Ríos (2007) sostiene que él recurre a la imagen "como al último refugio del significado, aunque esta ilusión de acceder al sentido (...) será posteriormente desmistificada" (245): los dibujos, las fotos, las pinturas están devaluados en su poder de revelación y son una "promesa incumplida de develamiento" (249). Esos recursos ópticos, según Carlos Labbé (2011), transparentan una ficción sobre el silencio y pretenden comunicar en un nivel icónico, la voluntad del relato de no designar nada que sea externo a él.

Esa incompetencia significativa es lo que hipercondensaría una novela como Los detectives salvajes. A pesar que allí Roberto Bolaño hace una concesión radical a la visualidad (Corro Pemjean, 2005), "al conferirle a unos miserables dibujos tramposos el honor de terminar la historia” (134) el marco de la ventana transparenta el punto de vista del universo narrativo, "que así como virtualiza lo que contiene por su irreductible parcialidad e inercia expresiva, se confunde y se pierde él mismo con lo descrito" (134).

La imagen en la literatura bolañeana, según Saucedo (2009), cumple por tanto una función metanarrativa: "historia, personajes, visión de la realidad y estructura encuentran en ella su traducción en un lenguaje visual de carácter abstracto, simbólico”. Es que, lejos del predicado tradicional, la figura se libera del dominio de la palabra pues ésta ya no logra explicarla, y sin posibilidad que se la fije o restrinja en sus potencias significativas, se abre a la plurisignificatividad.

El ejercicio visual de interpretación que propone la imagen, entonces, intensifica lo que es clave en la ficción de Roberto Bolaño: la ambigüedad. Es lo que propondría un texto como Estrella distante a través del motivo del doble. De acuerdo al estudio de Celina Manzoni (2002) esa abundancia de visión encapsula paradójicamente una contracara: la turbiedad, la incertidumbre. Por ello los juegos de desdoblamientos crean significados antinómicos: ficción/realidad; literatura/vida; yo/el otro, visión/invisibilización, presencia/ausencia, sentido/sinsentido.

Esa indeterminación aparece en principio bastante contradictoria con la "mirada clínica" de Roberto Bolaño. Éste, de acuerdo a Carlos Walker (2010), transparenta una visión desafectada y mecánica del mundo narrado, tan neutra que redundaría en una forma de decir o narrar, un lenguaje donde todo lo visible es enunciable. Es “(...) el gran mito de una pura Mira- 
da que sería puro Lenguaje: Ojo que hablaría" (Foucault citado en Walker, 2010: 106), un rigor descriptivo que en todo caso fracasa en su supuesta transparencia. En 2666 aquella modalidad narrativa se constituye en una manera de pensar la literatura:

La sucesión de diversos fragmentos, el desfile de mujeres encontradas sin vida, el tono desafectado de la pericia médica, la violencia de su silencio, y el entrecruzamiento de un sinfín de historias, conforman un conjunto a través del cual Roberto Bolaño pareciera interrogar las condiciones en las que se lleva a cabo la producción de la escritura (Walker, 2010: 111).

\section{Bolaño y la escritura miope}

El visualismo que recorre de manera transversal la obra de Roberto Bolaño trasunta en ficciones que prestan especial atención a la experiencia de mirar y ser mirado, a los dispositivos ópticos, a los espacios y lugares, a los cuerpos y a los significantes icónicos. También a los actantes cuyas funciones anclan en la capacidad de ver, como críticos, escritores, lectores, detectives, asesinos, policías, fotógrafos, artistas, viajeros y periodistas, a quienes se les demanda el ejercicio de la visión e incluso de una SÚPER/ visión.

Pero Bolaño discute el sentido y la función de la capacidad de ver. Su miopía ${ }^{2}$ es por tanto la mejor metáfora para entender una escritura que sospecha del vigor del ojo y desacredita al paradigma logocularcéntrico.

Una de las manifestaciones más evidentes de esta hostilidad visual aloja precisamente en los títulos de los textos que se analizan. Nocturno de Chile refiere lo oscuro y sombrío, la opacidad en la que se agazapa lo brutal, lo primitivo del ser humano, su momento más bárbaro y feroz. En Estrella

${ }^{2} \mathrm{Si}$ en el juego especular entre Roberto Bolaño y Arturo Belano aceptamos que este personaje es el alter ego del escritor, valga la siguiente descripción en Los detectives salvajes: "Era Arturo Belano. Tenía entonces veintiún años, era delgado, llevaba el pelo muy largo y usaba gafas, unas gafas horribles, aunque su miopía no era exagerada, apenas unas pocas dioptrías en cada ojo, pero las gafas igual eran horribles" (154). 
distante el enunciado privilegia al cuerpo celeste que observamos, pero que no es más que un espejismo: las estrellas que vemos son en definitiva una luz apagada, luz del pasado que sólo se distingue cuando la fuente de emisión ha desaparecido. Los detectives salvajes, por su parte, evoca al personaje del género policial (también llamado "private eye") quien, según Ricardo Piglia, es "el sujeto único, el individuo excepcional, el que sabe ver (lo que nadie ve)" (2005: 82). El adjetivo, sin embargo, sugiere una mirada indócil, desviada, fuera de foco. 2666, por su parte, hace un guiño al número que anuncia el fin de los tiempos, la desaparición radical de todo lo visible y, parafraseando a Baudrillard, a la transparencia del mal.

Bolaño contraviene la opción por el ojo a través del relato de una ausencia. Las diégesis se movilizan efectivamente en torno a lo oculto, representado de manera paradigmática en los escritores que se buscan. Nadie ha visto desde hace años a Cesárea Tinajero, la mentora del realvisceralismo, tanto así, que se inicia todo un "operativo detectivesco" para encontrarla y comprobar su existencia. De Benno von Archimboldi ni siquiera hay fotografías, nadie sabe cómo es ni dónde está: "Oiga -le dijo de pronto-, ¿no se decía que a usted no lo había visto nadie?” (2004: 138); y a pesar de ser un candidato al Nobel, el escritor alemán vive prácticamente en la clandestinidad, como un ermitaño, un fugitivo de sus críticos. En Estrella distante, Carlos Wieder se desvanece después de su último y bárbaro acto artístico-cultural y se oculta tras los seudónimos de artículos literarios o tras la cámara de videos pornográficos. En Nocturno de Chile, Ibacache obnubila a Sebastián Urrutia Lacroix, quien tras el seudónimo olvida hasta su propio nombre, y debe iniciar un viaje por su conciencia para intentar desentrañarlo.

La búsqueda de los autores perdidos toma la forma de una investigación policial, actividad que desde su nacimiento en la Europa del siglo XIX ha confiado en las potencias de la visión ${ }^{3}$. Pero la pesquisa en Bolaño queda

${ }^{3}$ La conformación de las grandes ciudades en Europa, y su creciente número de crímenes y delitos, gatilló la creación de los departamentos de policía modernos, cuyos procedimientos de prevención y búsqueda anclaron, de manera privilegiada, en competencias visuales. Se pusieron en marcha numerosos mecanismos (numeración de las viviendas, iluminación de las calles, huellas dactilares, documentos de identificación, registro por fotografías, etc.) que convirtieron a los ojos en el instrumento quintaesenciado para rastrear las huellas dejadas en la escena del crimen. 
frustrada, sin resultados y termina sin nada que ver. Jean Claude Pelletier, en 2666, dice al término de "La parte de los críticos": "Archimboldi está aquí (...) y nosotros estamos aquí, y esto es lo más cerca que jamás estaremos de él" (Bolaño, 2004: 207). En Estrella distante, el detective Abel Romero y Belano dan con Wieder en Lloret, pero a pesar del encuentro en el bar, el asesino sigue siendo un enigma, un personaje del que se conocen sólo sus crímenes, pero que sus perseguidores no pueden transparentar: Belano y Wieder se miran "pero en medio de la oscuridad total. No, total no, en medio de una oscuridad lechosa, como en el interior de una nube negra” (Bolaño, 1996: 152). Tan incompetente puede ser la búsqueda de los detectives bolañeanos que a veces ellos mismos provocan la invisibilización más radical: Belano y Lima encuentran a Tinajero solo para llevarle la muerte.

Junto a los autores, las obras también destacan por su ausencia. En efecto, no se conoce la producción poética de los numerosos escritores que desfilan por Los detectives salvajes. Conforme a la mística vanguardista, parecen ser artistas que optan por la invisibilización editorial y por una experiencia vital de la literatura. Tampoco se sabe cuál es la producción textual de Cesárea Tinajero, quien dirigió "con sigilo" el primer (y último) número del órgano oficial del movimiento realvisceralista, la revista $\mathrm{Ca}$ borca, nombre que alude a la localidad ubicada en Sonora, zona desértica, despoblada y escasa, donde los ojos chocan con el vacío. La invisibilidad de la poetisa se agudiza si se considera que las únicas producciones realmente textuales de Tinajero tuvieron un carácter secreto y oculto: redactaba los discursos que después pronunciaba, en público, el general Diego Carvajal.

Pero cuando la obra efectivamente existe tampoco da garantías de transparencia o lucidez. Es el caso del mínimo y extraño poema "Sión", única obra reconocible de Tinajero y compuesta sólo de significantes icónicos. Allí, la palabra, la dimensión verbal del arte literario, se borra y lo que parece al principio como un ensalzamiento de la capacidad de ver, se disuelve después como una manifestación de crítica visual. Es que el letrismo, corriente de vanguardia a la que pueden ser atribuidas las figuras del poema, hay que entenderlo como un repliegue respecto de una norma comunicativa basada en la claridad y la transparencia lingüística. En su reemplazo, se propone una obra oscura, donde lo visual tiende a la opacidad carente de significado. Así, la literatura visual de "Sión" postula una 
entidad no representacional, opuesta a un realismo o un naturalismo que confía en el registro de una realidad dispuesta para la observación de un narrador omnividente.

La misma imposibilidad de abordar el texto se reconoce en Estrella distante, donde Carlos Wieder es un poeta que escribe con la cauda de su avión: poesía pasajera, en huida, escrita para fugarse. En 2666, por su parte, la baronesa von Zumpe confiesa que en ningún momento se ha dado la oportunidad de leer algún texto de Archimboldi pues rara vez leía novelas "oscuras y difíciles" (Bolaño, 2004: 1081).

Ni la crítica, paradigmática actividad de observación, logra transparentar a los textos y sus autores y opera, en el universo narrativo de Bolaño, como factor de invisibilización. En 2666 los profesores Jean-Claude Pelletier, Manuel Espinoza, Piero Morini y Liz Norton inician la búsqueda de Archimboldi, pero en el camino se desvían al ritmo de las pulsiones o delirios personales. Y en Nocturno de Chile, el crítico acaba sus días siendo el foco de atención de la mirada fantasmal de un "joven envejecido". En esta novela, Ibacache concuerda con Farewell que la crítica es un "esfuerzo 'dilucidador' y 'civilizador' de la literatura”, pero su intento de significación termina cercado por las instancias políticas y económicas, neutralizado por sus coqueteos con la autoridad. Urrutia Lacroix definitivamente no quiere ver lo que su complicidad con el poder le impide. Él, que era "un hombre razonable", un crítico para quien el ejercicio hermenéutico era "como un humilde faro en la costa de la muerte", pero que ante la mirada dominante (la de Farewell o la de Pinochet) baja "los ojos humildemente, como un pájaro herido" (15).

La insuficiencia del exégeta también queda quitaesenciado al final de 2666. Ninguno de los estudiosos de Archimboldi, lectores supuestamente superiores, es capaz de reconocer en El rey de la selva el mecanismo de camuflaje del autor al escribir su autobiografía en tercera persona.

Lo que propone Bolaño es entonces el cuestionamiento de la capacidad del ojo como mecanismo de conocimiento. Esa incompetencia visual es la que demuestran los "ojos interiores" del crítico Ibacache, en Nocturno de Chile. El sacerdote necesita "aclarar ciertos puntos" de su recorrido vital para lo cual inicia un viaje al pasado para visibilizar aquellos recuerdos que le permitan justificarse. Pero su búsqueda la hace desde la penumbra de su desmejorada condición, por lo que su esfuerzo de claridad termina con 
imágenes que se transponen y confunden, recuerdos difusos y confusos que lo tienen en el ojo de una "tormenta de mierda".

Incluso ciertos recursos de acercamiento visual de la realidad que parecen tener garantía de certidumbre son desacreditados por Bolaño. La fotografía, por ejemplo. En principio se trata de un dispositivo que da cuenta, incuestionablemente, de la existencia de alguien o algo. En Estrellla distante, La Gorda concluye que Carlos Wieder y Ruiz Tagle son la misma persona a partir de una foto que se publica en El Mercurio, y en 2666 la imagen fija es la única manera de reconocer a las mujeres asesinadas. Esta capacidad de instalar certezas es tan potente, que cuando no hay registro fotográfico se duda de la ocurrencia de los hechos. El detective Romero, por ejemplo, no tiene ninguna instantánea que acredite que recibió la Medalla al Valor. Lo mismo pasa con Archimboldi, cuya existencia es cuestionable precisamente porque sus libros aparecen "sin fotos en la solapa o en la contraportada" (Bolaño, 2004: 30).

Pero la miopía de Roberto Bolaño lo empuja a menoscabar la capacidad de revelación de la fotografía y la presenta como mero estímulo visual, uno más de los destellos de un festival de formas y colores que se queda en puro gesto o impostura. Es lo que se desprende de la necrofílica exposición de Carlos Wieder, un artista criminal que exhibe las instantáneas perversas de los cuerpos torturados de sus víctimas. Las capturas, sin embargo, no logran develar el misterio que se esconde tras ellas, el asesino, y todo queda en una espectacularización del horror que provoca en los asistentes reacciones propias "de los sonámbulos y de los idiotas" (Bolaño, 1996: 98).

La imagen pictórica también es presentada como una estafa visual. La figura de Benno von Archimboldi, por ejemplo, se entiende como una alusión a Giuseppe Arcimboldo, un pintor italiano recordado por sus creaciones manieristas que, tras el despliegue de frutas, flores, animales, plantas y otros objetos, esconde figuras antropomorfas. Lo visual es tratado por el artista milanés como ilusión: "Semejantes a las pinturas de Arcimboldo (diseñador de vitrales, ilusionista, manierista, es decir, dandi), las novelas de B., compuestas de parcialidades y disgresiones, de silencios e infinitos, sugieren también una morbidez del vacío (...): no hay sentido, no hay una suma, sólo hay una agregación de partes, que se montan sin jamás fundirse del todo (...) El arte es un juego de ilusiones, al fin" (Franz citado en Paz Soldán y Faverón Patriau, 2008: 113). 
Igual que un artista visual, Bolaño propone una ficción que resulta de un juego de acercamientos y distancias con lo referido y entre cuyos extremos las figuras se anamorfizan. Su mirada miope estrecha el foco, se acerca demasiado al objeto que conoce y entrega una imagen exagerada. Lejos de la armonía, el escritor chileno escribe con lentes de súper aumento, y esa mirada le devuelve una ficción intensa y mayúscula. El resultado es una ficción excesiva, delirante y desbocada donde no hay relación económica con la escritura. Es lo que ocurre en Los detectives salvajes y en 2666. Allí, en La parte de los crímenes, abundan hasta la saciedad las descripciones hiperpormenorizadas de los cuerpos de las mujeres asesinadas:

El siete de octubre fue hallado a treinta metros de las vías del tren (...) el cuerpo de una mujer de edad comprendida entre los catorce y los diecisiete años. El cuerpo presentaba señales claras de tortura, con múltiples hematomas en brazos, tórax y piernas, así como heridas punzantes de arma blanca (...) ninguna de las cuales, sin embargo, penetró algún órgano vital (...). Según el forense la causa de la muerte fue estrangulamiento. El pezón del pecho izquierdo presentaba señales de mordeduras y estaba medio arrancado, sosteniéndose tan sólo en algunos cartílagos (Bolaño, 2004: 724).

A finales de septiembre fue encontrado el cuerpo de una niña de trece años, en la cara oriental del cerro Estrella [...] su pecho derecho había sido amputado y el pezón de su pecho izquierdo arrancado a mordidas. Vestía pantalón de mezclilla de marca Lee, de buena calidad, una sudadera y un chaleco rojo. Era muy delgada. Había sido violada repetidas veces y acuchillada y la causa de la muerte era rotura del hueso hioides (Bolaño, 2004: 584).

En el caso de Mónica Posadas, ésta no sólo había sido violada 'por los tres conductos' sino que también había sido estrangulada. El cuerpo, que hallaron semioculto detrás de unas cajas de cartón, estaba desnudo de la cintura para abajo [...] La vagina estaba desgarrada. La vulva y las ingles presentaban señales claras de mordidas y desgarraduras, como si un perro callejero se las hubiera intentado comer (Bolaño, 2004: 577).

El mismo recurso está en Nocturno de Chile donde se relatan las sesiones de tortura que practica Jimmy Thompson en la casa que comparte con la escritora María Canales. Allí, en un sótano oscuro, el funcionario de los servicios de seguridad aplica electroshocks a los presos políticos: 
(...) y abrió la puerta y vio al hombre atado a una cama metálica, los ojos vendados, y supo que el hombre estaba vivo porque lo oyó respirar, aunque su estado físico no era bueno, pues pese a la luz deficiente vio sus heridas, sus supuraciones, como eczemas, pero no eran eczemas, las partes maltratadas de su anatomía, las partes hinchadas, como si tuviera más de un hueso roto, pero respiraba, en modo alguno parecía alguien a punto de morir, y luego (...) cerró delicadamente la puerta, sin hacer ruido, y empezó a buscar el camino de vuelta a la sala (Bolaño, 2000: 140).

Pero los textos analizados no sólo menosprecian el poder de la visión, sino que, en una propuesta más extrema, exaltan algunas manifestaciones degradadas del espectro visual ${ }^{4}$. En Bolaño los que poseen la verdad son los personajes cuyas potencias de percepción son tradicionalmente cuestionadas por su estatuto marginal. En 2666, por ejemplo, está Florita Almada, una vidente que "desde hacía relativamente poco, diez años, había recibido la iluminación” (535). Invitada al programa de televisión Una hora con Reinaldo, la médium dice: "Los putos policías no hacen nada, sólo miran, ¿pero qué miran?, ¿qué miran?”.

Lo mismo sucede con Joaquín Font, en Los detectives salvajes, cuya locura pareciera ser garantía de lucidez y claridad. Se trata de un guiño más de Bolaño a la impotencia del ojo: los que ven claramente lo que los demás no pueden, están instalados en un contexto rebajado respecto al esquema óptico dominante.

${ }^{4}$ Hay que considerar que el ojo no sólo ha sido hegemónico en el ámbito epistemológico central. En ámbitos domésticos y descentrados o marginales, nuestras vidas diarias también están matizados por aquel sesgo. El mal de ojo, el talento de los videntes y clarividentes para "ver más allá", la capacidad para expresar emociones a través de los ojos, considerados por ello como "espejos del alma"; las premoniciones; el poder mágico de los espejos y su capacidad de doblamientos infinitos; la centralidad de ciertas ciudades, prototípicamente visuales como París, Nueva York o Las Vegas; las expresiones culturales como la moda, el cine, la fotografía; fenómenos como internet, Facebook o realities que anclan en la actitud voyeurista del espectador; sin olvidar la importancia que el ver tiene en las religiones (fuego sagrado, cultos solares, iconografía religiosa, la "luz" del mundo, la imagen como hechizo y su poder de fascinación). 


\section{La escritura oscura}

Pero los gestos de resistencia al ocularcentrismo trascienden la diégesis y también pueden reconocerse en la propuesta escritural de Roberto Bolaño. El discurso de Los detectives salvajes está compuesto fuera de proyecciones panorámicas y totalizantes. De acuerdo a su miopía, la focalización de Bolaño es fragmentaria, opera de plano en plano, de ahí su composición multiperspectivista: una historia que se presenta a través de las miradas de varios espectadores que intervienen de acuerdo a sus prerrogativas de conocimiento. Esta visión múltiple del mundo narrado configura un abanico de versiones de los hechos, estrategia que eclipsa al narrador como figura tradicionalmente asociada a quien todo lo ve y todo lo sabe, y que cuestiona su pretensión mimética de dar cuenta de una realidad objetiva, única y unívoca.

El multiperspectivismo se asocia a las limitadas potencias "visuales" de quien mira. Frente al vigilante panóptico, y su pretensión de totalidad, el nuevo "observador" se alimenta de fracciones. Roberto Bolaño se rebela contra la figura del Gran Intérprete y presenta un narrador que ha perdido el privilegio del sentido y del saber y que se resta de la tarea omnivisibilizadora tradicional. Y así, escritas bajo la estética del fragmento, las narraciones bolañeanas dan cuenta de una realidad múltiple, imposible de asir desde una única y suficiente dimensión.

La escritura del autor chileno también destaca por los efectos de oralidad. La enfermedad del ojo fortalece lo audible en sus ficciones, tanto, que de acuerdo a la célebre recomendación de Borges, sus palabras "hay que oírlas, no leerlas"5. Los monólogos en Los detectives salvajes, los interrogatorios en 2666 o las memorias en Nocturno de Chile, son recursos que imprimen una entonación al relato y privilegian el oído como sentido de conocimiento. El texto en Bolaño, parafraseando a Ricardo Piglia (2000), se articula en la posibilidad de oír un relato escrito y escribir un relato que se pueda escuchar.

Paradigmático es en este sentido el discurso del segundo capítulo de Los detectives salvajes, articulado sobre la base de 93 monólogos, de 53

${ }^{5}$ La idea es estudiada por Rodríguez Fernández (2009). 
personajes distintos, que se anteceden con la identificación del hablante y sus referencias temporales y espaciales. De acuerdo a esas condiciones de enunciación, a las características de dichos discursos y a determinadas marcas textuales que identifican al narratario, se proponen como las transcripciones de un discurso oral, verdadero registro de las respuestas a las preguntas de uno o más interrogadores.

La estrategia antivisual también está reforzada con la pluridiscursividad. La desaparición de un registro discursivo predominante, y por tanto la proliferación de un lenguaje diverso y descentrado, se manifiesta en la convergencia textual de autobiografía, diario íntimo, crítica literaria, libro de viaje, periodismo, historiografía, metaliteratura, entrevista, expediente policial, conversación. Es decir, se trata de una escritura híbrida, eclecticismo que da cuenta de un arte que se ubica lejos de las pretensiones de unidad y claridad de la tradición novelística dominante. La pluralidad discursiva invisibiliza a la obra concebida como unidad, producto acabado y completo.

En cuanto a la espacialización, las historias que se analizan están instaladas prioritariamente en lugares donde no hay nada que ver. Los detectives salvajes y 2666 transcurren en el desierto mexicano, allí donde "se esconde el secreto del mundo" (Bolaño, 2004: 439), y Nocturno de Chile se instala en el fundo Là-bas, un territorio alejado de la urbe, situado "allá abajo"; incluso en el entorno urbano de esta ficción, en la casa de la escritora María Canales, hay un lugar oscuro, un sótano feroz, ajeno a las posibilidades de percepción visual.

En otros casos la estrategia de ambientación es notoriamente opuesta, pero conduce al mismo efecto de ocultamiento. En las cuatro novelas estudiadas los lugares de enunciación y de las historias se multiplican a tal escala que clausuran cualquier posibilidad de asentamiento, escondiendo un lugar central y estabilizador desde el cual comprender el mundo narrado.

Esta dispersión cartográfica implicaría la renuncia a un criterio único desde el cual entender lo literario y puede ser entendida como un gesto de Bolaño para defender la categoría que George Steiner definió como extraterritorialidad, una escritura multilingüe que cuestiona las categorías que afirman lo local y lo nacional y se abre a las perspectivas de lo global, lo universal y lo diverso. El mismo escritor chileno puede dar fe de este nomadismo: su vida, en tránsito por diferentes lugares, lo convirtió en un artista en permanente exilio. Parafraseando a Todorov (2000), Bolaño personifica 
un perfil propio de nuestra sociedad: el que ha perdido su patria sin adquirir otra y que vive en esa doble exterioridad.

\section{Conclusiones}

La literatura miope de Roberto Bolaño sospecha de la imagen uniforme y regularizada del mundo. Es que el poder ha ocupado el espacio del lenguaje y lo ha usado como mecanismo de control, seleccionando y distribuyendo su producción: el propietario del decir ha determinado el orden del discurso y la forma de ver las cosas. Por otro lado, el artista se ve desenmascarado en su gratuidad, en su condición concreta y en su historicidad. La naturaleza mediadora de la palabra le impide ser la expresión de la conciencia de un sujeto que pretende reconocerse en sus atributos esenciales y de esa forma percibirse y afirmarse a sí mismo en su entorno:

La actividad del artista, practicada en un mundo lleno de percepciones de segunda mano, y ofuscada específicamente por la traición de las palabras, carga con la maldición de la mediatez. El arte se convierte en el enemigo del artista, porque le niega su realización -la trascendenciaque desea (Sontag, 2009).

Frente a ese destino órfico, el escritor chileno parece recurrir a lo icónico como intento de significación, a la visión como el sentido que accede a la verdad, como el "último refugio del significado" en palabras de De los Ríos (2007). Pero si los ojos generan expectativas de revelación, su ametropía le entrega solo espejismos e ilusiones de desciframiento y al igual que la escritura, la imagen se le confiesa incompetente en su condición simbólica y epistemológica.

Por eso Bolaño ficcionaliza una mirada enferma y abatida. Su escritura rehúye los intentos de iluminación que hace el poder y más bien oculta, deforma y anamorfiza, horadando un régimen ocularcéntrico que ha pretendido por siglos implantar una imagen regular, misma y armónica del hombre y su entorno. Bolaño destroza las visiones sujetas al logos y la disciplina y se presenta en cambio como un artista insuficiente para dar cuenta de la calidad de la experiencia, incompetente en la empresa de que el mundo destile un sentido. 
Ojo y lenguaje, entonces, en su afán gnoseológico, se perfilan como intentos absurdos de explicar el significado. Si Milan Kundera dice que el objetivo hacia el cual se precipita el hombre queda siempre velado, Bolaño explora y hace el registro ficcional de esa zona oscura. Tras rasgar los velos de la apariencia, el escritor siempre encuentra un espacio vacío y desde ese lugar relata. El sentido de la obra literaria se abre así hacia lo inefable, quedando como un concepto vacío, algo que no se puede "ver".

Frente a la tragedia, algunos tienden a la autoalienación y hacia lo que Susan Sontag denomina el antiarte: el silencio, el vacío. Varios autores lo han suscrito. Arthur Rimbaud cortó nexo con la poesía cuando sólo tenía 19 años. Maurice Blanchot, Jerome David Salinger, María Luisa Bombal, Juan Rulfo o Friedrich Hölderin también hicieron ese ejercicio de renuncia. Es que, según Sontag, "los diversos públicos han experimentado la mayor parte del arte valioso de nuestro tiempo como un paso hacia el silencio (o hacia la ininteligibilidad, la invisibilidad o la inaudibilidad); como un desmantelamiento de la competencia del artista, de su sentido vocacional responsable" (2009).

Otros eligen un camino distinto: la escritura febril, obsesiva, al modelo medieval... a lo Bolaño. Se trata del postulado de Samuel Beckett: en literatura no hay nada que expresar, "nada que sirva de punto de partida para expresar, ni poder para expresar, ni deseo de expresar a lo cual se suma la obligación de expresar" (Sontag, 2009).

Pero ¿qué decir? La respuesta es no/velar la ausencia, la falta, lo invisible. Porque lejos de la aporía, el vacío algo muestra. No existe obra de arte que no se manifieste, no existen los discursos neutrales o los grados ceros de la presencia o el silencio. La vacuidad comunica en los textos de Bolaño, él oculta para visibilizar:

Mientras el ojo humano mire, siempre habrá algo que ver. Cuando miramos algo que está "vacío”, no por ello dejamos de mirar, no por ello dejamos de ver algo...aunque sólo sean los fantasmas de nuestras propias expectativas (...) El vacío genuino, el silencio puro, no son viables, ni conceptualmente ni en la práctica (Sontag, 2009).

La falta de visión se extrapola en estrategias ficcionales de ocultamiento, deformación, degradación, aumento o exageración de la experiencia. Sus historias fluyen en un juego de acercamientos y distancias respecto de 
los objetos de observación, donde se oculta y eclipsa por un lado, y aumenta y exagera por otro. Ambas, en todo caso, son tentativas para velar.

Por un lado, nada se puede "ver". Los espacios que el ojo enfermo no alcanza se trasladan a la ficción como la ausencia de los escritores, los textos, los críticos, el sentido de las obras o la interpretación. El resultado es el relato de una ausencia. Las ficciones bolañeanas se tejen en torno a lo oculto, a lo que es buscado pero nunca encontrado, aquello que esquiva la luz que pretende toda empresa de conocimiento/saber. La escritura como "arte de lo implícito": la narración visible eclipsa una trama escondida y el significado, por tanto, adopta la estructura del secreto. Esta invisibilización tiene una consecuencia doble: literatura de la ausencia, por un lado, ausencia de la literatura, por otro. Lo que se cuenta es la historia de una falta. Lo que falta, el sentido, es lo que no se cuenta.

De acuerdo a lo anterior, Bolaño adheriría a una estética de la desaparición, un fenómeno estimulado, según Paul Virilio, por las nuevas tecnologías y fundado en la velocidad de la toma fotográfica, en la resistencia retiniana de las imágenes y en su fugacidad: “(...) el desarrollo de altas velocidades técnicas dará por resultado la desaparición de la conciencia en cuanto percepción directa de los fenómenos que nos informan sobre nuestra propia existencia" (1988: 120). Este fenómeno se manifiesta en una mirada que pierde su poder y provoca la desintegración de la vista, "que precede muy poco a la de la materia y los cuerpos" (55). En ese contexto de invisibilidad, Bolaño intenta visualizar.

Por otro lado, el ojo enfermo estimula un exceso de visión. Es que sin posibilidad de sentido, la literatura se convierte en intensidad, experimentación, puro gesto: relatos que provocan el vértigo de la proximidad. La extensión de los textos, la potencia de las historias, la descripción médica de cuerpos y acontecimientos operarían por acumulación que, siguiendo a Virilio, significa la "suspensión pura y simple por aceleración" (1988: 23). También contribuyen el mensaje recargado, el discurso esquizofrénico, la condensación de información, los detalles clínicos, la escritura extrema del mal. Es la literatura como ejercicio de presentación más que de representación, el privilegio de mostrar más que de demostrar.

Obligado a ver deforme, Bolaño propone un relato donde LA verdad, EL significado del mundo representado detenta un sentido nómade, siempre en fuga, imposible de aprehender en la completud y univocidad que supone 
el racionalismo secular. Los textos del escritor chileno exudan la imposibilidad de restablecer el orden e imponer cierta lógica, de establecer causas y deducir efectos: es la apoteosis de la incertidumbre:

Belano, le dije, el meollo de la cuestión es saber si el mal (o el delito o el crimen o como usted quiera llamarle) es casual o causal. Si es causal, podemos luchar contra él, es difícil de derrotar pero hay una posibilidad, más o menos como dos boxeadores del mismo peso. Si es casual, por el contrario, estamos jodidos. Que Dios, si existe, nos pille confesados. Y a eso se resume todo (Bolaño, 1998: 397).

Cuando se cree estar cerca del centro, Bolaño enreda, complejiza y hace ver el mundo "en el espejo convexo de los Arnolfini”. Parafraseando a Bersani (1975), su universo narrativo se enmarca en un sistema en el cual el desorden es profundo. Se trata de la constatación de que "el sujeto y la obra son, por esencia, incompletos, demostrando que jamás se instalan en las significaciones definitivas, que reducen el trabajo artístico a un simple descubrimiento de verdades psicológicas" (17).

Lo que hace Bolaño entonces es tomar vistas de la realidad (impresiones, fotos, registros ópticos) considerando que todo lo que se ofrece a la visión en el instante de la mirada es la tiranía de la inmediatez. Su literatura está hecha de miradas ¿̇y qué hay más inmediato y fugaz, más condicionado por las coordenadas del aquí y el ahora ${ }^{6}$, que una “ojeada”?

Las instantáneas que expone Bolaño cuestionan la mirada totalizadora y esencialista de la realidad que impone un poder con vocación abarcante y fundacional. En su escritura priman la imagen localizada, el episodio, el fragmento sin pretensión de sentido. Se trata de la transformación, según Virilio (2001), de un espacio-tiempo a un espacio-velocidad: la experiencia se vuelve una imagen que genera una visibilidad cronoscópica, matizada por la inmediatez: nuestra forma de ver el mundo ya no es secuencial, progresiva o extensiva sino fraccionada. La consecuencia es una decadencia de la mirada, ojos que por más que quieran seguir mirando ya no pueden encontrarse frente a frente con la verdad, un concepto que por ello se ha vuelto relativo y permeable. Es lo in/visible y lo in/significante.

\footnotetext{
${ }^{6}$ Basta recordar las condiciones de enunciación que preceden a los monólogos de la segunda parte de Los detectives salvajes.
} 


\section{Referencias}

Bersani, L. (1975). El realismo y el temor al deseo. Poétique 22, 177-195. Traducido por Gabriela Mogillanski. Disponible en BiblioFyL, biblioteca digital de los estudiantes de Filosofía y Letras de la Universidad de Buenos Aires: http://biblioteca.cefyl.net

Bolaño, R. (1996). Estrella distante. Barcelona: Anagrama. . (1998). Los detectives salvajes. Barcelona: Anagrama. . (2000). Nocturno de Chile. Barcelona: Anagrama. . (2004). 2666. Barcelona: Anagrama.

Corro Pemjean, P. (2005). Dispositivos visuales en los relatos de Roberto Bolaño. Revista Aisthesis, 38, 123-135.

Debray, R. (1994). Vida y muerte de la imagen. Historia de la mirada en Occidente. Barcelona: Paidós.

De los Ríos, V. (2007). Cartografía salvaje: mapa cognitivo y fotografías en la obra de Bolaño. Taller de Letras, 41, 69-81.

Foucault, M. (1968). Las palabras y las cosas. Buenos Aires: Siglo XXI Editores.

. (2008). Vigilar y castigar. Nacimiento de la prisión. Buenos Aires: Siglo XXI Editores.

Jay, M. (2007). Ojos abatidos. La denigración de la visión en el pensamiento francés del siglo XX. Madrid: Ediciones Akal.

Labbé, C. (2011). Silencio y significados de Los detectives salvajes, de Roberto Bolaño. Revista Letras.s5.com. Disponible en www.letras.s5.com/ clo70411.html

Manzoni, C. (2002). Roberto Bolaño: la escritura como tauromaquia. Buenos Aires: Corregidor.

Paz Soldán, E. y Faverón Patriau, G. (2008). Bolaño salvaje. Barcelona: Candaya.

Piglia, R. (2000). Formas breves. Barcelona: Anagrama. . (2005). El último lector. Barcelona: Anagrama.

Rodríguez Fernández, M. (2004). Novela y poder. El panóptico. La ciudad apestada. El lugar de la confesión. Atenea, 490, 11-32.

. (2009). Oír y no leer a Bolaño. La entonación oral de la prosa. Universum, 24 (2), 154-171.

Saucedo, F. (2009). Forma y función del discurso visual en la novela Los detectives salvajes de Roberto Bolaño. Ciberletras 22. Disponible en http:// www.lehman.cuny.edu/ciberletras/v22/saucedo.html

Sontag, S. (2009). Estética del silencio. Disponible en http://es.scribd.com/ doc/14661869/Estetica-del-silencio-Susan-Sontag

Tabarovsky, D. (2011). Literatura de izquierda. Rosario: Beatriz Viterbo Editora. 
Todorov, T. (2000). La Conquista de América. El problema del otro. México, D. F.: Siglo XXI.

Virilio, P. (1988). Estética de la desaparición. Madrid: Anagrama. . (2001). El procedimiento silencio. Buenos Aires: Paidós.

Walker, C. (2010). El tono del horror: 2666 de Roberto Bolaño. Taller de Letras, 46, 99-112. 